\title{
Histidyl-Proline Diketopiperazine (His-Pro DKP) Immunoreactivity Is Present in the Glucagon-containing Cells of the Human Fetal Pancreas
}

\author{
Patrick Leduque, * Ivor M. D. Jackson," Alain Kervran," Sonia Aratan-Spire," Paul Czernichow," and Paul-M. Dubois" \\ *Centre National de la Recherche Scientifique, Unité Associée 559, Faculté de Médecine Lyon-Sud, 69921 Oullins Cédex, France; ${ }^{\ddagger}$ Brown \\ University, Rhode Island Hospital, Providence, Rhode Island 02902; ${ }^{8}$ Centre National de la Recherche Scientifique/Institut National de la \\ Santé et de la Recherche Médicale, Unité 264, 34033 Montpellier Cédex; and "Institut National de la Santé et de la Recherche Médicale, \\ Unité 30, Hôpital des Enfants Malades, 75743 Paris Cédex 15, France
}

\begin{abstract}
Histidyl-proline diketopiperazine (His-Pro DKP) cells in the pancreas of human fetuses aged between 12 and 19 wk were localized by the indirect antibody-enzyme method on semithin sections. To study their fine structure, two techniques were used: a superimposition technique consisting of comparison of the same cells in semithin and electron microscopic preparations, and an immunocytochemical technique on ultrathin sections using the unlabeled antibody peroxidase-antiperoxidase method. Our results show that $(a)$ the same cells are positive for both His-Pro DKP and glucagon/glicentin, (b) His-Pro DKP immunoreactive cells possess extremely electron-opaque secretory granules, implying that these cells correspond to the A cells, and (c) HisPro DKP immunoreactivity is found over the secretory granules. We hypothesize that the two peptides His-Pro DKP and thyrotropin-releasing hormone (TRH) have independent origins, since TRH is found in the B cells.
\end{abstract}

\section{Introduction}

Histidyl-proline diketopiperazine (His-Pro DKP), ${ }^{1}$ a cyclic dipeptide initially described in both the hypothalamus and cerebral tissues (1-4), has been detected in various sites outside the central nervous system $(5,6)$, including the gastrointestinal tract and, more specifically, the endocrine pancreas (7). There has been some controversy over the relationship of endogenous His-Pro DKP to thyrotropin-releasing hormone (TRH). Although it was initially proposed that His-Pro DKP was a metabolite of TRH (8-11), recent studies suggest that most of His-Pro DKP is independent of the tripeptide amide $(12,13)$. Pancreatic His-Pro DKP appears to be chromatographically and immunologically identical to the synthetic dipeptide (7), but its role is unknown. The cyclic dipeptide is not localized in the insulin-containing cells, since His-Pro DKP content, unlike TRH (14), remains unaltered after the selective destruction of B cells by streptozotocin (7).

Address reprint requests to Dr. Leduque, CNRS UA 559, Faculte de Medecine Lyon-Sud, Laboratoire d'Histologie, Chemin du Petit Revoyet, B.P. 12, 69921 Oullins Cedex, France.

Received for publication 28 July 1986.

1. Abbreviations used in this paper: G-37, oxyntomodulin; His-Pro DKP, histidyl-proline diketopiperazine; PP, pancreatic polypeptide; TRH, thyrotropin-releasing hormone.

J. Clin. Invest.

(c) The American Society for Clinical Investigation, Inc.

0021-9738/87/03/0875/06 \$1.00

Volume 79, March 1987, 875-880
In the present experiment we examined the localization of His-Pro DKP immunoreactivity in the human fetal pancreas by light and electron microscopic immunocytochemistry. This model offers a number of potential advantages in clarifying the origin of His-Pro DKP. While pancreatic TRH is easily detected in the fetal and early neonatal period in the rat, the levels gradually decline during the neonatal period and are basely detectable in the adult (15-18). In contrast, the content of His-Pro DKP in the pancreas peaks in the adult rat (12). In light of preliminary studies demonstrating the simultaneous occurrence of both insulin and TRH immunoreactivity in the same islet cells of the human fetal pancreas (19), we have used this system to further clarify the cellular location of His-Pro DKP and its relationship to TRH.

\section{Methods}

Tissue collection. Eight pancreatic glands were collected from human fetuses (six females and two males) delivered after legal abortions. The crown-rump length of the fetuses ranged from 6 to $14 \mathrm{~cm}$ (i.e., 12-19 wk of gestation) (20). Our study was carried out according to guidelines established by the National Ethical Committee of France.

Tissue preparation. To preserve His-Pro DKP immunoreactivity, a combination of $p$-formaldehyde $(4 \% \mathrm{wt} / \mathrm{vol})$ and low glutaraldehyde $(0.5 \%$ $\mathrm{vol} / \mathrm{vol}$ ) was used in the primary fixation step, followed by postfixation with $1 \%$ osmium tetroxide as reported for TRH (19). After embedding in araldite, semithin $1-\mu \mathrm{m}$ and ultrathin $90-\mathrm{nm}$ sections were cut. Semithin sections were deresinated for 10-30 min with sodium ethoxide (21). Semithin or ultrathin sections of postosmicated tissue were then pretreated with a strong oxidizing agent (as described below) before processing for immunocytochemistry.

Pretreatment of the postosmicated tissue. Before labeling, semithin or ultrathin sections were treated in three different ways: $(a)$ incubation for 10 min with $0.3-10 \%$ hydrogen peroxide solution $(22) ;(b)$ incubation for $10 \mathrm{~min}$ with $1-5 \%$ periodic acid solution (23); and $(c)$ incubation for $10,20,30,60$, and 120 min with saturated sodium metaperiodate (24).

Primary antisera. Antiserum to synthetic His-Pro DKP (Peninsula Laboratories, Inc., Belmont, CA) (No. 1068) was raised in a New Zealand White rabbit immunized with the peptide coupled to bovine thyroglobulin by the bis-diazotized benzidine procedure as reported for TRH (25). This antiserum exhibits no cross-reactivity with its constituent amino acids, pGlu-His, TRH free acid, or gonadoliberin in radioimmunoassay, and $\sim 0.17 \%$ cross-reactivity with TRH (13). For immunocytochemistry, the antiserum was used at a titer of 1:500.

Antiserum to pure porcine pancreatic glucagon (Novo Research Unit, Copenhagen, Denmark) was prepared at the Unité 264, Montpellier, France. This antibody (No. GAN 8) was obtained from a New Zealand White rabbit inoculated with the peptide conjugated to bovine serum albumin with carbodiimide (26). Scatchard analysis indicates an equilibrium constant of $6.10^{11}$ liters $/ \mathrm{mol}$ and a binding capacity of $638 \mathrm{nmol} /$ liter. The specificity of the antiserum was tested by adding $0.01-100$ nmol TRH, His-Pro DKP, human glucagon-like peptides GLP1 and 2, rat pancreatic polypeptide (PP), peptide histidine-isoleucine, peptide histidine-methionine (PHM), peptide tyrosine-tyrosine (Peninsula Lab- 
oratories, Inc.), bombesin, neurotensin, somatostatin (Bachem, Bubendorf, Switzerland), secretin, vasoactive intestinal peptide (a gift from Dr. E. Wunsch, Max Planck Institute, Munchen, Federal Republic of Germany), synthetic cholecystokinin (a gift from Dr. J. Martinez, Unité 264, Montpellier, France), and rat insulin (Novo Research Institute). None of these peptides demonstrated cross-reactivity with the antiserum (Fig. 1). The relative affinities for $\mathrm{COOH}$-terminal glucagon fragment $\mathrm{F}$ 13-26 obtained by endopeptidase digestion and for porcine oxyntomodulin G-37 (G-37) (supplied by Dr. D. Bataille, Unité 264, Montpellier, France) were 0.1 and $2 \%$, respectively. Dilutions of a crude rat intestinal extract shared the same pattern of cross-reactivity as G-37 (Fig. 1). For immunocytochemistry, the anti-hormone serum was used at a titer of $1: 5,000$.

The following specific rabbit primary antisera were also used: antiinsulin No. 24-2 (kindly donated by Dr. R. Assan, Hôpital Bichat, Paris, France) diluted 1:5,000; anti-somatostatin No. 19608 (kindly donated by Dr. M. P. Dubois, Institut National de la Recherche Agronomique; Nouzilly, France) diluted 1:1,000; anti-bovine PP No. 146-6 (kindly donated by Dr. R. E. Chance, Lilly Research Laboratories, Indianapolis, IN) diluted 1:5,000; and anti-glicentin No. R-64 (kindly donated by Dr. A. J. Moody, Novo Research Institute) diluted 1:5,000. Full characterization of these primary antisera have been reported elsewhere (27-32).

Immunocytochemistry on semithin sections: light and electron microscopy. The immunocytochemical procedure performed on serial $1-\mu \mathrm{m}$ sections using the goat anti-rabbit immunoglobulin $\mathrm{G}$ conjugated to peroxidase (33) was applied as described previously (30). Semithin sections were examined in a Zeiss light microscope. For electron microscopy, immunoreactive cells were photographed and the corresponding ultrathin sections of the same cells, contrasted with lead citrate, were examined in an Elmiskop 101 electron microscope. The mean values (in nanometers) of granule profile diameter were characterized with the aid of the $95 \%$ confidence limits (mean $\pm 1.96[\mathrm{SD} / \sqrt{\mathrm{n}}]$ ).

Immunocytochemistry on ultrathin sections. The unlabeled antibody peroxidase-antiperoxidase method (34) was applied as described previously (22). The grids were contrasted with lead citrate before observation.

Primary antisera specificity controls. To test for specificity, antiserum to His-Pro DKP was absorbed with the corresponding antigen (Peninsula Laboratories, Inc.) at concentrations of $10-1,000 \mathrm{nmol} / \mathrm{ml}$ undiluted antiserum for $1 \mathrm{~h}$ at $37^{\circ} \mathrm{C}$. Absorbed antiserum or nonimmune serum were used instead of freshly diluted primary antiserum on control sections. All staining was abolished by absorption of primary antiserum at 250 nmol. Absorption of the anti-His-Pro DKP with heterologous hormones (pancreatic and brain peptides) or hormone fragments (also see reference 19) gave no change in the reaction. The immunoreaction due to anti$\mathrm{COOH}$-terminal-specific glucagon, anti-glicentin, anti-insulin, anti-somatostatin, or anti-PP was quenched by the corresponding antigen (also see reference 19 ).

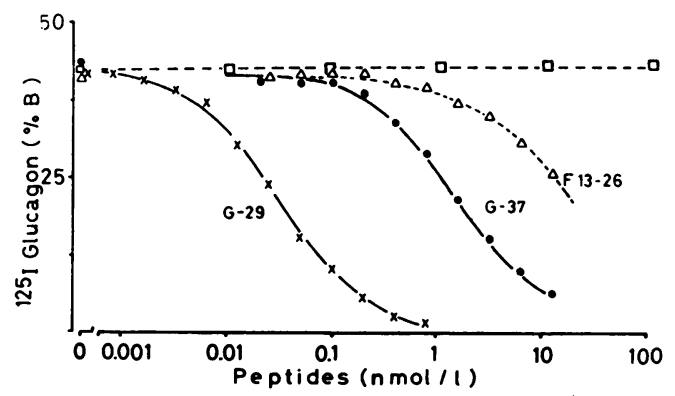

Figure 1. Cross-reactivity of GAN 8 antiserum with $\mathrm{COOH}$-terminal glucagon fragment F 13-26 $(\Delta)$ and G $37(\bullet)$, compared to glucagon G-29 ( $\times$ ). Other peptides $(\square)$ were also tested: bombesin; CCK, cholecystokinin; His-Pro DKP; GLP 1 and GLP 2, glucagon-like peptides 1 and 2; insulin; neurotensin; PHI, peptide histidine-isoleucine; PHM, peptide histidine-methionine; PYY, peptide tyrosine-tyrosine; PP; secretin; VIP, vasoactive intestinal peptide; and TRH. Antiserum dilution $1: 80,000$.

\section{Results}

Technical aspects of His-Pro DKP immunostaining. Among the different oxidizing agents tested, sodium metaperiodate was found to be the most suitable, giving dense labeling over perfectly preserved structures (Figs. 2-4). The restoration of His-Pro DKP immunoreactivity with sodium metaperiodate was found to be time dependent: after 10 min of treatment on deresinated semithin sections, intense labeling was observed, but unsatisfactory results were obtained after $20 \mathrm{~min}$. On ultrathin sections, maximal labeling intensity was reached between 30 and $60 \mathrm{~min}$. A slight decrease in immunostaining occurred when $1-5 \%$ periodic acid was used, whereas the least reactivity was obtained with 0.3-10\% hydrogen peroxide.

Location of His-Pro DKP immunoreactive cells. Antiserum to His-Pro DKP stained endocrine-type cells in the pancreatic gland of 12-19-wk-old human fetuses. The immunoreaction was present in all the pancreatic islets of the female and male fetuses investigated. At the light microscope level, immunoreactive cells were interspersed among the islet cell clusters at the 12th week of gestation (Fig. $2 A$ ), and later (16 wk) inside the recognizable islets of Langerhans (Fig. 2 C). His-Pro DKP immunoreactivity was entirely confined to the peripheral parts of the typical islets (Fig. 2 C). It was present throughout the pancreatic gland, but its distribution was heterogeneous. Immunoreactive cells were numerous in the superior part of the head, in the body and in the tail, but were only very scarce in the lower posterior part of the head. The exocrine tissue of the fetal pancreas was unstained. Also, no nerve cells or fibers within the pancreas contained HisPro DKP immunoreactivity.

Interrelationship of cells immunoreactive to His-Pro DKP and other hormone antisera. Consecutive semithin sections of 12-19-wk-old fetuses were stained alternately with His-Pro DKP and $\mathrm{COOH}$-terminal-specific glucagon antisera. As shown in Fig. 2, the same cells in the islet cell clusters (12 wk) or in the typical islets (16-19 wk) revealed the simultaneous occurrence of both His-Pro DKP and COOH-terminal glucagon immunoreactivity. Similar results were obtained after substitution of glicentin antiserum (that specifically recognizes the glucagon precursor, also see reference 35 ) in place of the $\mathrm{COOH}$-terminalspecific glucagon antiserum. In contrast, the His-Pro DKP immunoreactive cells were distinct from insulin- and somatostatincontaining cells in the superior part of the head, in the body, and in the tail. No His-Pro DKP immunoreactivity could be detected in the numerous cells containing pancreatic polypeptide of the lower posterior part of the head.

Ultrastructural characterization of His-Pro DKP immunoreactive cells. A superimposition technique, using semithin sections for immunocytochemistry and consecutive ultrathin sections for ultrastructural characterization, were then adopted. His-Pro DKP immunoreactive cells observed in the consecutive ultrathin sections all shared a number of characteristics. They possessed a population of extremely electron-opaque secretory granules with two components: an eccentric spherical core and a granular mantle, the latter usually less dense (Fig. 3). The granule profile diameter varied considerably within a given cell and between different cells, and ranged from 250 to $600 \mathrm{~nm}$; their size distribution is shown in Fig. 5. The mean value (nanometers \pm confidence limits $95 \%$ ) of the profile diameter was 416 44.14. His-Pro DKP immunoreactive cells corresponded to the A cells. As shown in Fig. 3, there was another cell type with granules $\sim 300-600 \mathrm{~nm}$ in diameter, but whose granules dis- 

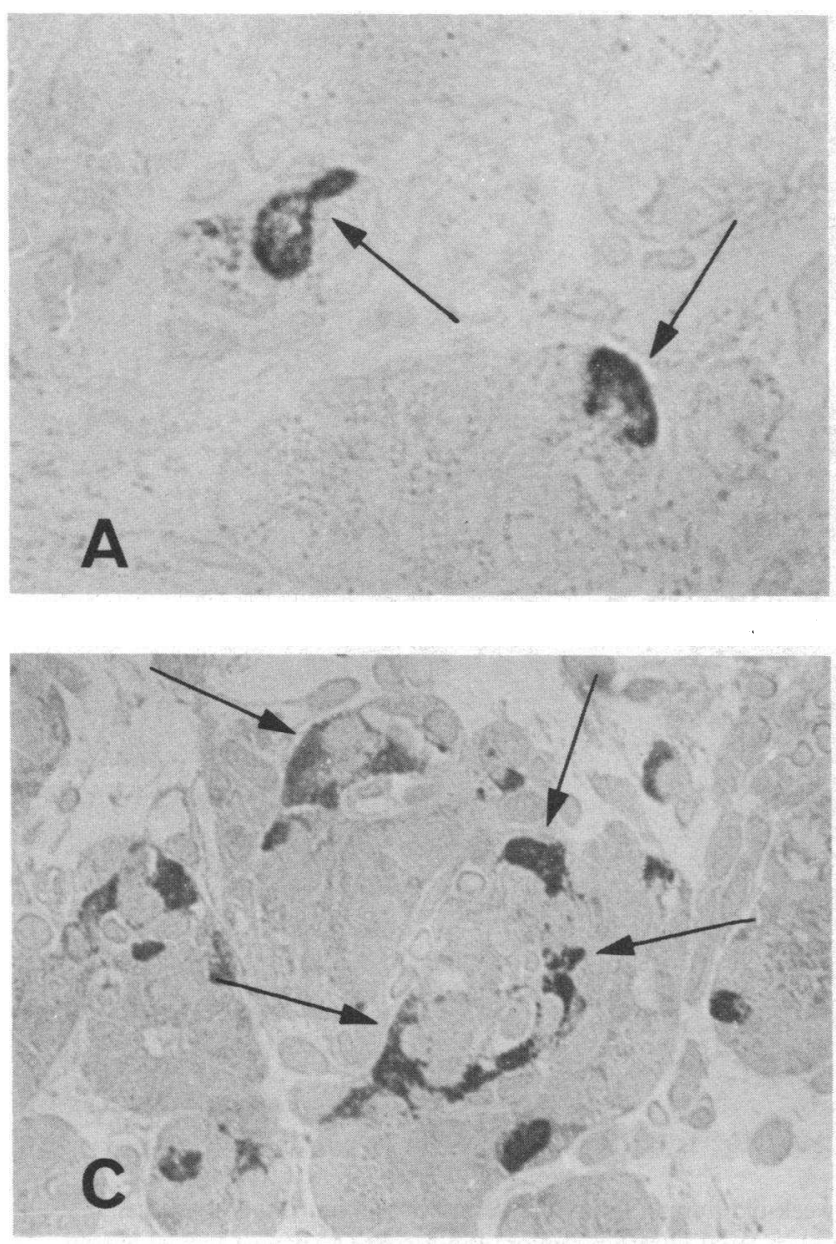

Figure 2. Developmental pattern of His-Pro DKP/glucagon immunoreactive cells. Consecutive semithin sections stained with His-Pro DKP (A, C) and COOH-terminal-specific glucagon (B, D) antisera. (A, B) 12-week-old human fetus: the His-Pro DKP/glucagon cell reacting both to His-Pro DKP and COOH-terminal-specific glucagon antisera

played a paracrystalline core and a broad halo. This cell type was referred to as B cells. As previously reported (19), the mean profile diameter (nanometers \pm confidence limits $95 \%$ ) was $442 \pm 5.04$. The $D$ cells, in contrast, contained large granules $(\sim 300-950 \mathrm{~nm}$ in diameter) with clear contents surrounded by a broken limiting membrane (Fig. 3). The mean profile diameter (nanometers \pm confidence limits $95 \%$ ) was $716 \pm 7.78$. The $B$ and D cells were not stained on semithin sections (Fig. 3).

Ultrastructural localization of His-Pro DKP. Immunocytochemical staining with His-Pro DKP antiserum gave a precise localization of the cyclic dipeptide in the cytoplasmic granules. The reaction product (electron-dense precipitates at least $30 \mathrm{~nm}$ in diameter) was deposited on electron-opaque secretory granules, leading to the conclusion that these cells corresponded to the A cells (Fig. 4). The reaction product usually stained the whole surface of the secretory granules (Fig. 4), as reported for glucagon (19).

\section{Discussion}

His-Pro DKP has been measured biochemically in the pancreas and, more specifically, in the islets of Langerhans, however its
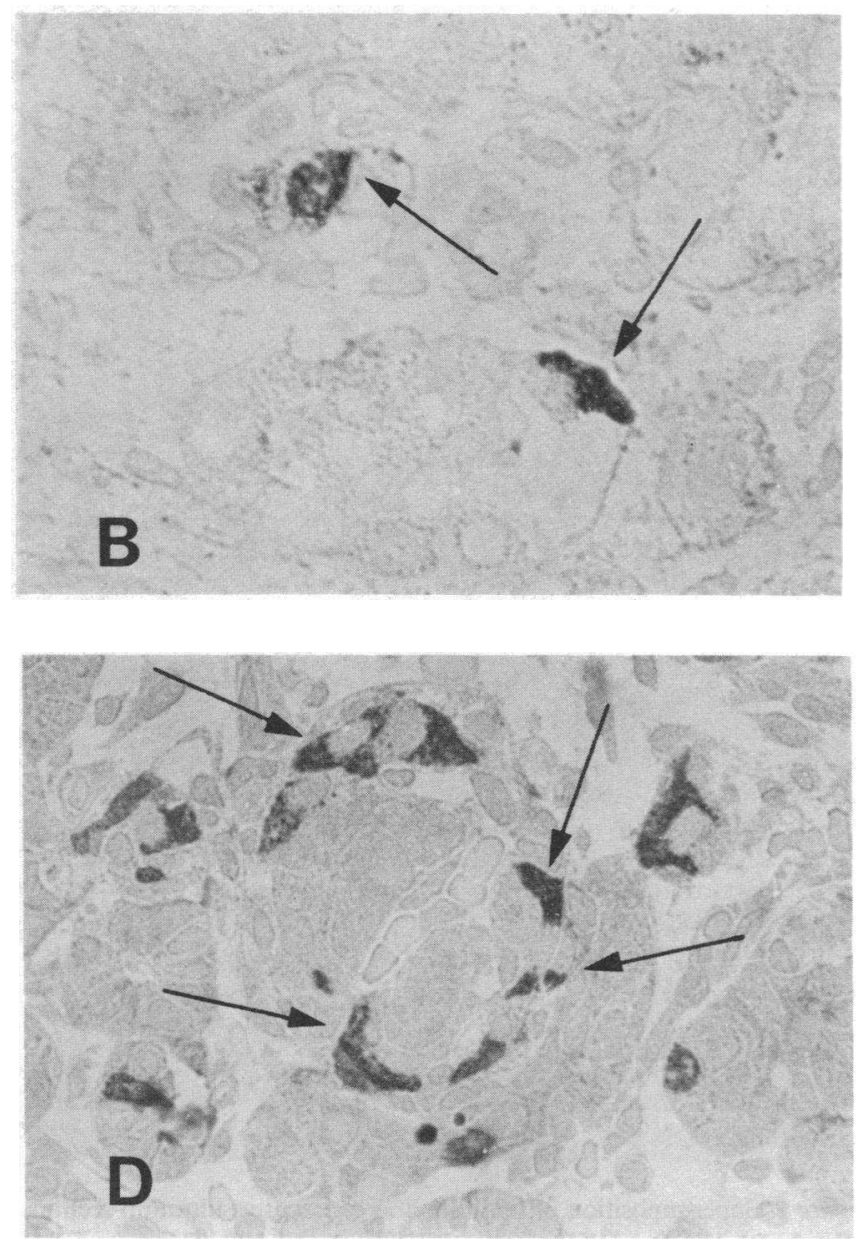

(arrows) is present in the islet cell clusters. $\times 1,500$. (C, D) 19-weekold human fetus: the His-Pro DKP/glucagon cell stained by both antisera (arrows) is present in the peripheral part of the islets of Langerhans. $\times 1,100$.

precise localization was unknown except that the cyclic dipeptide is not concentrated in streptozotocin-sensitive cells (7). As reported herein, its cellular location in the A cells revealed by immunocytochemistry may be taken as indicative of a potential relationship to other hormones and of functional relations between His-Pro DKP and the endocrine pancreas.

In the present paper, we have reported the presence of a strong His-Pro DKP immunostaining in the human fetal pancreas. Its cellular location has been assigned to an endocrinetype cell, predominantly confined to the periphery of islets. A general problem with immunocytochemical methods is the specificity of the technique, especially the possible existence of cross-reacting antibodies. This is a particularly important issue when using antisera raised to small peptides, such as the cyclic dipeptide His-Pro DKP. The radioimmunoassay and absorption tests suggest that each primary antiserum is not only specific to one peptide family but that, within its family, it is also specific to the peptide that has produced the antiserum.

Three techniques were used to characterize its localization: (a) consecutive semithin sections alternately stained with HisPro DKP and other antisera; $(b)$ superimposition of immunocytochemical and electron microscopic observations on the same cells; and $(c)$ immunocytochemical staining on ultrathin sections. 


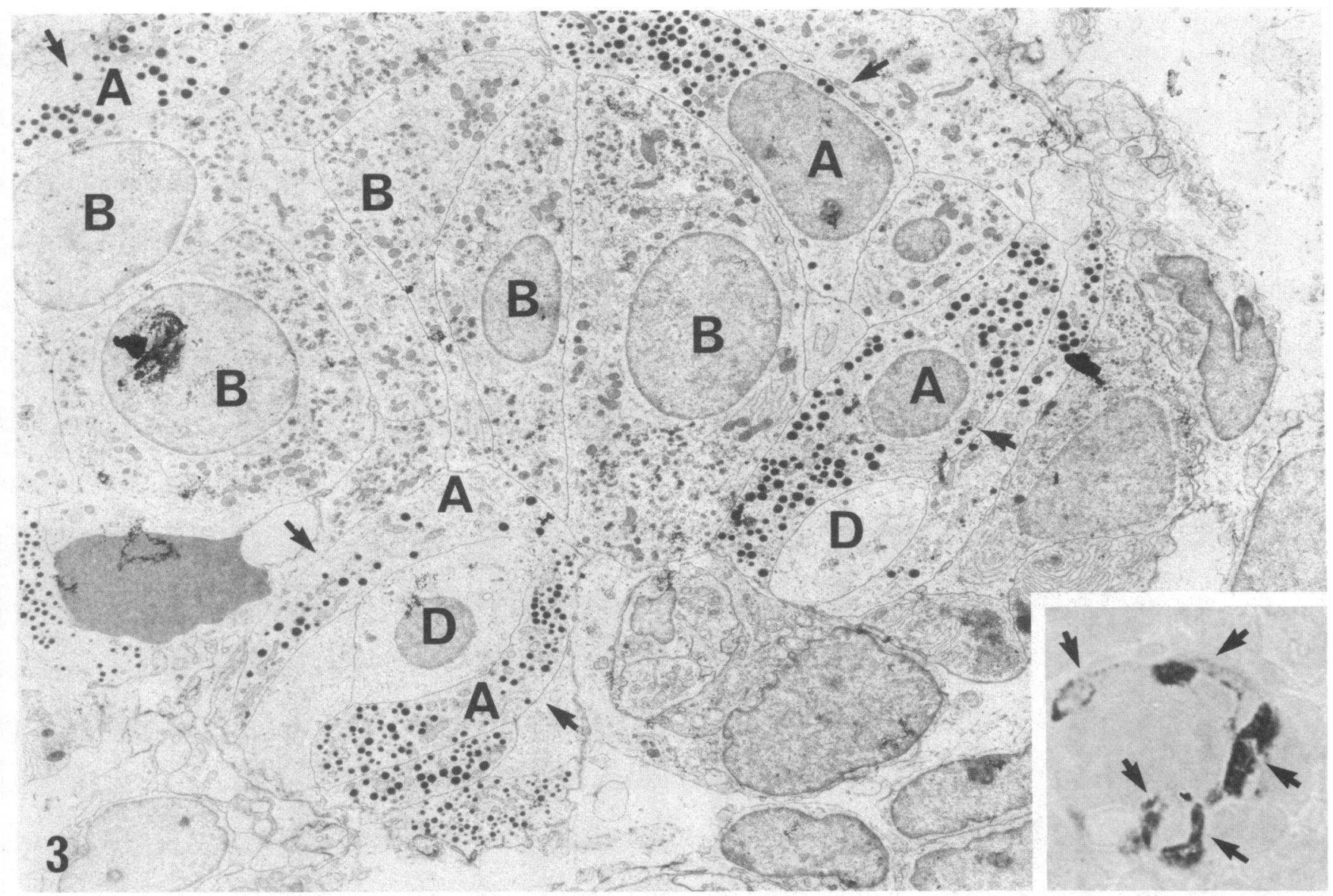

Figure 3. Superimposition of semithin and consecutive ultrathin sections. 19-week-old human fetus. The semithin section (inset) shows cells stained with His-Pro DKP antiserum (arrows). $\times 1,500$. The same cells (arrows) in serial ultrathin section: the A cells (A) have a typical appearance with an eccentric electron-dense core and a thin halo; note the presence of $B(B)$ and $D(D)$ cells. $\times 6,000$.

The first technique established whether different peptides were present in the same cells. His-Pro DKP immunoreactivity was seen exclusively in glucagon immunoreactive cells. Second, the superimposition technique permitted an excellent description

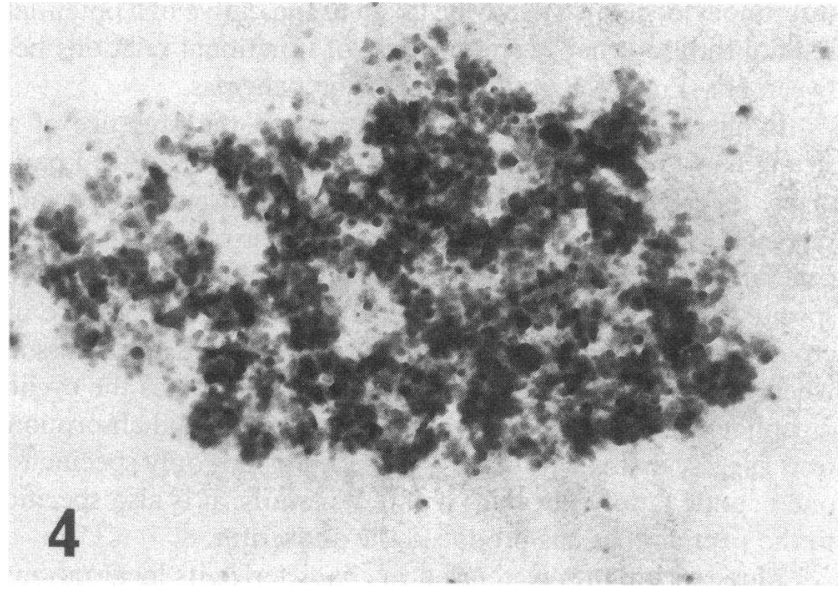

Figure 4. Electron micrograph of a portion of an islet A cell stained with His-Pro DKP antiserum. The reaction product is confined to $\mathrm{A}$ cell secretory granules. $\times 28,000$. of ultrastructure of individual cells of each type. With this method, we were able to describe the His-Pro DKP immunoreactive cells as cells with electron-dense granules ranging in size from 250 to $600 \mathrm{~nm}$. This cell type was referred to as A cells $(36,37)$. With the third technique, more information was gained about the subcellular localization of His-Pro DKP. The immunoreactivity was found over all the secretory granules.

Morphological techniques have previously established the developmental profile of the different endocrine pancreatic cell populations and, more specifically, they have allowed identification of A cells in early fetal life (8 wk) (38). By radioimmunoassay, it has been documented that glucagon and glucagonlike immunoreactants are detected at the end of the 8th week with specific ( $\mathrm{COOH}$ terminal) and nonspecific $\left(\mathrm{NH}_{2}\right.$ terminal)

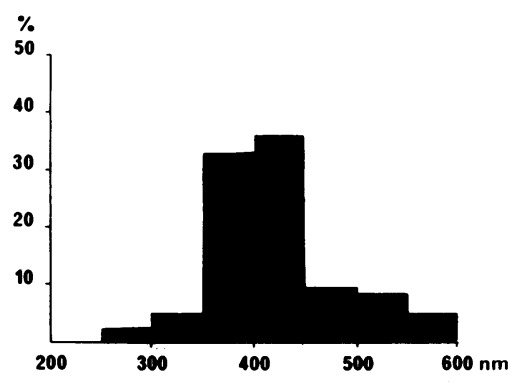

Figure 5. Distribution of granule profile diameters in A cells of the human fetal pancreas. 
glucagon antisera, respectively (39). Using immunocytological techniques, it has been observed that glucagon-containing cells are present from $8 \mathrm{wk}$; the occurrence of glucagon immunoreactivity is accompanied by glicentin (one glucagon-like immunoreactant; also see reference 35$)$ immunoreactivity $(30,40)$. At present it is not known whether this fetal glucagon/glicentin cell is a cell type different from the His-Pro DKP cell producing glucagon/glicentin, or whether it represents a transitional stage in the differentiation of the pancreatic A cell. However, we have noted that the developmental pattern of His-Pro DKP is identical to that of glucagon/glicentin between 12 and $19 \mathrm{wk}$; moreover, His-Pro DKP is restricted to the lobe rich in glucagon/ glicentin, suggesting that such a peculiar distribution could be related to an embryological origin from the dorsal primordium (28). Because true pancreatic-type glucagon has been traced to the glicentin-containing cells in the fetal $(41,42)$ and adult (4345) human gastrointestinal tract, it will be interesting to check whether the intestinal L cell also contains His-Pro DKP.

The eventual implications of His-Pro DKP in the development of the pancreatic gland of the human fetus are open to discussion. It has been suggested that His-Pro DKP could be a metabolic breakdown product of TRH (8-11). Because the putative parent tripeptide TRH has been assigned to the pancreatic B cells in neonatal (46), streptozotocin-treated newborn (14), and hypothyroid (32) rat, and in the human fetus (19), we further hypothesize $(12,13)$ that the two peptides His-Pro DKP and TRH have independent origins. Recently the presence of HisPro DKP immunoreactivity in the mammalian cerebrospinal fluid has been reported (47). This study also suggests that at least a certain portion of His-Pro DKP may be derived from sources independent of TRH. There is, however, one report of pancreatic TRH in some of the cells reactive to glucagon antiserum in developing rat pancreas (46). Unfortunately, absorption tests with the His-Pro DKP antigen were not carried out in that study. One report has also indicated a possible role in the modulation of islet hormonal responses to nutrients, and in the catecholaminergic control of islet secretory events (7). If the co-localization of His-Pro DKP and glucagon is confirmed by other techniques, His-Pro DKP may play a role in glucagon physiology. However, it is not inconceivable that other roles may exist, specifically related to the regulation of differentiation and/or growth of fetal cells.

\section{Acknowledgments}

The authors wish to express our appreciation and thanks to Dr. M. Dumont, Hôpital de la Croix-Rousse, Lyons, Dr. J. M. Thoulon, Hôtel Dieu, Lyons, Dr. D. Dargent, Hôpital Edouard Herriot, Lyons, and Dr. M. Bethenod, Hôpital Debrousse, Lyons, France, for their cooperation. We thank Miss F. Hemming for preparation of this manuscript, and Mrs. M. Tschora for her patience and superb secretarial assistance.

Dr. Jackson was supported in part by a grant from the National Institutes of Health (AM-34540).

\section{References}

1. Mori, M., A. Jayaraman, C. Prasad, J. Pegues, and J. F. Wilber. 1982. Distribution of histidyl-proline diketopiperazine (cyclo (His-Pro)) and thyrotropin-releasing hormone (TRH) in the primate central nervous system. Brain Res. 245:183-186.

2. Mori, M., C. Prasad, and J. F. Wilber. 1982. Regional dissociation of histidyl-proline diketopiperazine (cyclo-(His-Pro)) and thyrotropinreleasing hormone (TRH) in the rat brain. Brain Res. 231:451-453.
3. Prasad, C., M. Mori, J. F. Wilber, W. Pierson, J. Pegues, and A. Jayaraman. 1982. Distribution and metabolism of cyclo (His-Pro): a new member of the neuropeptide family. Peptides. 3:591-598.

4. Prasad, C., M. Mori, W. Pierson, J. F. Wilber, and R. Edwards. 1983. Developmental changes in the distribution of rat brain, pyroglutamate aminopeptidase, a possible determinant of endogenous cyclo (HisPro) concentrations. Neurochem. Res. 8:389-399.

5. Mori, M., J. Pegues, C. Prasad, R. Edwards, and J. F. Wilber. 1982. Distribution and characterization of cyclo (His-Pro)-like immunoreactivity in the rat gastrointestinal tract. Biochem. Biophys. Res. Commun. 109:982-987.

6. Kandarakis, E. D., T. Iriuchijima, C. Prasad, and J. F. Wilber. 1985. Distribution and characterization of cyclo (His-Pro)-like immunoreactivity in the human gastrointestinal tract. Neuropeptides. 6:2125.

7. Mori, M., J. Pegues, C. Prasad, J. F. Wilber, J. Peterson, and S. Githens. 1983. Histidyl-proline diketopiperazine cyclo (His-Pro): identification and characterization in rat pancreatic islets. Biochem. Biophys. Res. Commun. 115:281-286.

8. Prasad, C., and A. Peterkofsky. 1976. Demonstration of two separate enzymatic activities for the degradation of thyrotropin-releasing hormone in hamster hypothalamic extracts. J. Biol. Chem. 251:32293234.

9. Prasad, C., T. Matsui, and A. Peterkofsky. 1977. Antagonism of ethanol nacrosis by histidyl-proline diketopiperazine. Nature (Lond.). 268:142-144.

10. Matsui, T., C. Prasad, and A. Peterkofsky. 1979. Metabolism of thyrotropin-releasing hormone in brain extracts: isolation and characterization of an imidopeptidase for histidylprolineamide. J. Biol. Chem. 254:2439-2445.

11. Peterkofsky, A., and F. Battaini. 1980. The biological activities of the neuropeptide histidyl-proline diketopiperazine. Neuropeptides. 1: 105-118.

12. Lamberton, R. P., R. M. Lechan, and I. M. D. Jackson. 1984. Ontogeny of thyrotropin-releasing hormone and histidyl-proline diketopiperazine in the rat central nervous system and pancreas. Endocrinology. 115:2400-2405.

13. Lechan, R. M., and I. M. D. Jackson. 1985. Thyrotropin-releasing hormone but no histidyl-proline diketopiperazine is depleted from rat spinal cord following 5,7-dihydroxytryptamine treatment. Brain Res. 326:152-155.

14. Aratan-Spire, S., B. Wolf, B. Portha, D. Bailbe, and P. Czernichow. 1984. Streptozotocin-treatment at birth induces a parallel depletion of thyrotropin-releasing hormone and insulin in the rat pancreas during development. Endocrinology. 114:2369-2373.

15. Koivusalo, F., and J. Leppäluoto. 1979. Hight TRH immunoreactivity in purified pancreatic extracts of fetal and newborn rats. Life Sci. 24:1655-1658.

16. Martino, E., H. Seo, A. Lernmark, and S. Refetoff. 1980. Ontogenetic patterns of thyrotropin-releasing hormone-like material in rat hypothalamus, pancreas and retina: selective effect of light deprivation. Proc. Natl. Acad. Sci. USA. 77:4345-4348.

17. Engler, D., M. F. Scanlon, and I. M. D. Jackson. 1981. Thyrotropin-releasing hormone in the systemic circulation of the neonatal rat is derived from the pancreas and other extraneural tissues. J. Clin. Invest. 67:800-807.

18. Aratan-Spire, S., B. Wolf, and P. Czernichow. 1984. Developmental pattern of TRH-degrading activity and TRH content in rat pancreas. Acta Endocrinol. (Copenh.). 106:102-108.

19. Leduque, P., S. Aratan-Spire, P. Czernichow, and P. M. Dubois. 1986. Ontogenesis of thyrotropin-releasing hormone (TRH) in the human fetal pancreas. A combined radioimmunological and immunocytochemical study. J. Clin. Invest. 78:1028-1034.

20. Hamilton, W., J. Boyd, and H. Mossman. 1972. Growth of the embryo and fetus. In Human Embryology. W. Heffer and Sons, editors. Williams \& Wilkins Co., Baltimore. 174-191.

21. Lane, B. P., and D. L. Europa. 1965. Differential staining of 
ultrathin sections of epon-embedded tissues for light microscopy. J. Histochem. Cytochem. 13:579-582.

22. Moriarty, G. C., and N. S. Halmi. 1972. Electron microscopic study of the adrenocorticotropin producing cell with the use of unlabeled antibody and the soluble peroxidase-antiperoxidase complex. J. Histochem. Cytochem. 20:590-603.

23. Casanova, P. 1974. Techniques de coloration des tissues osmiés et inclus dans l'araldite ou l'épon. Ann. Anat. Pathol. 19:231-243.

24. Bendayan, M., and M. Zollinger. 1983. Ultrastructural localization of antigenic sites on osmium-fixed tissues applying the protein A-gold technique. J. Histochem. Cytochem. 31:101-109.

25. Jackson, I. M. D., and S. Reichlin. 1974. Thyrotropin-releasing hormone (TRH): distribution in hypothalamic and extrahypothalamic brain tissues of mammalian and submammalian chordates. Endocrinology. 95:855-862.

26. Goodfriend, T. L., L. Levine, and G. D. Fasman. 1964. Antibodies to bradykinin and angiotensin: a use of carbodiimide in immunology. Science (Wash.). 144:1344-1346.

27. Dubois, P. M., C. Paulin, R. Assan, and M. P. Dubois. 1975. Evidence for immunoreactive somatostatin in the endocrine cells of human foetal pancreas. Nature (Lond.). 256:731-732.

28. Paulin, C., and P. M. Dubois. 1978. Immunohistochemical identification and localization of pancreatic polypeptide cells in the pancreas and gastrointestinal tract of the human fetus and adult man. Cell Tissue Res. 188:251-257.

29. Chayvialle, J. A., C. Paulin, P. M. Dubois, F. Descos, and M. P. Dubois. 1980. Ontogeny of somatostatin in the human gastrointestinal tract, endocrine pancreas and hypothalamus. Acta Endocrinol (Copenh.). 94:1-10.

30. Leduque, P., A. J. Moody, and P. M. Dubois. 1982. Ontogeny of immunoreactive glicentin in the human gastrointestinal tract and endocrine pancreas. Regul. Pept. 4:261-274.

31. Leduque, P., C. Paulin, and P. M. Dubois. 1983. Immunocytochemical evidence for a substance related to the bovine pancreatic polypeptide-peptide YY group of peptides in the human fetal gastrointestinal tract. Regul. Pept. 6:219-230.

32. Leduque, P., B. Wolf, S. Aratan-Spire, P. M. Dubois, and P. Czernichow. 1985. Immunocytochemical location of thyrotropin-releasing hormone (TRH) in the B-cells of adult hypothyroid rat pancreas. Regul. Pept. 10:281-292.

33. Nakane, P. K., and G. B. Pierce. 1966. Enzyme-labeled antibodies: preparation and application for the localization of antigens. J. Histochem. Cytochem. 14:929-931.

34. Sternberger, L. A., P. H. Hardy, J. J. Cuculis, and H. G. Meyer.
1970. The unlabeled antibody-enzyme method of immunohistochemistry. Preparation and properties of soluble antigen-antibody complex (horseradish peroxidase-antihorseradish peroxidase) and its use in identification in spirochetes. J. Histochem. Cytochem. 18:315-333.

35. Moody, A. J., F. Sundby, and H. Jacobsen. 1978. The tissue distribution and plasma levels of glicentin (gut GLI-1). Scand. J. Gastroenterol. 13(Suppl. 49):127. (Abstr.)

36. Björkman, N., C. Hellerström, B. Hellman, and B. Petersson. 1966. The cell types in the endocrine pancreas of the human fetus. $Z$. Zellforsch. Mikrosk. Anat. 72:425-445.

37. Wellmann, K. F., B. W. Volk, and P. Brancato. 1971. Ultrastructure and insulin content of the endocrine pancreas in the human fetus. Lab. Invest. 25:97-103.

38. Like, A. A., and L. Orci. 1972. Embryogenesis of the human pancreatic islets: a light and electron microscopic study. Diabetes. 21(Suppl. 2):511-534.

39. Assan, R., and J. Boillot. 1973. Pancreatic glucagon and glucagonlike material in tissues and plasma from human fetuses 6-26-week-old. Pathol. Biol. 21:149-155.

40. Stefan, Y., M. Ravazzola, S. Grasso, A. Perrelet, and L. Orci. 1982. Glicentin precedes glucagon in the developing human pancreas. Endocrinology. 110:2189-2191.

41. Ito, S., T. Iwanaga, Y. Kusumoto, N. Sudo, M. Sano, T. Suzuki, and A. Shibata. 1981. Is glucagon present in the human gastric fundus? Horm. Metab. Res. 13:419-422.

42. Ravazzola, M., R. H. Unger, and L. Orci. 1981. Demonstration of glucagon in the stomach of human fetuses. Diabetes. 30:879-882.

43. Knudsen, J. B., J. J. Holst, S. Asnaes, and A. Johanse. 1975. Identification of cells with pancreatic-type and gut-type glucagon immunoreactivity in the human colon. Acta Pathol. Microbiol. Immunol. Scand. Sect. A. 83:741-743.

44. Garaud, J. C., R. Eloy, A. J. Moody, C. Stock, and J. F. Grenier. 1980. Glucagon- and glicentin-immunoreactive cells in the human digestive tract. Cell Tissue Res. 213:121-136.

45. Colony, P. C., V. Helmstaedter, A. J. Moody, J. C. Garaud, and W. G. Forssmann. 1982. Glucagon and glicentin immunoreactive cells in human colon. Cell Tissue Res. 221:483-491.

46. Kawano, H., S. Daikoku, and S. Saito. 1983. Location of thyrotropin-releasing hormone-like immunoreactivity in rat pancreas. Endocrinology. 112:951-955.

47. Prasad, C., T. Iriuchijima, J. K. Rao, J. F. Wilber, and A. Jayaraman. 1986. Distribution and characterization of cyclo (His-Pro)-like immunoreactivity in human cerebrospinal fluid. Biochem. Biophys. Res. Commun. 136:835-842. 